\title{
Reducing Isolation through Regional Mentors and Learning Communities: A Way to Support Rural Learners
}

\author{
Nancy Glomb \\ Tressa Midenhall \\ Lee L. Mason \\ Charles Salzberg \\ Utah State University
}

\begin{abstract}
Reinforcing and facilitating learning communities is a strategy that has been used to decrease attrition rates in traditional campus-based programs, and it has been hypothesized that applying principles of learning communities in distance education programs could have similar positive outcomes. To facilitate the development and maintenance of regional learning communities within the Mild/Moderate Distance Degree and Licensure Program at Utah State University, highly successful graduates of the program are employed as mentors within each broadcast locality to engineer regional opportunities for studying and socialization. Program evaluation respondents indicate that mentoring experiences were very helpful as they progressed through the courses and practica. Moreover, graduation rates increased from $\mathbf{5 3} \%$ to $75 \%$ since the inception of this approach.
\end{abstract}

In the last 10 years, the number of undergraduate and graduate students who participate in distance education programs has steadily increased (Parsad \& Lewis, 2008). Students are opting to participate in distance versus traditional campus-based courses for a variety of reasons, such as the lack of geographic proximity to university classrooms and financial or family obligations that preclude attendance in traditional campus-based programs (Braun, 2008; Riffell \& Sibley, 2004; Yudko, Hirokawa, \& Chi, 2008). Increasing the pool of potential new teachers by providing access for all qualified applicants to special education teacher training programs via distance education programs is particularly pertinent in light of nation-wide shortages of special education teachers (Katsiyannis, Zhang, \& Conroy, 2003), especially in rural areas (Menlove \& Lignugaris/Kraft, 2004; Sundeen \& Wienke, 2009; Williams, Martin, \& Hess, 2002).

Distance teacher preparation programs have become an increasingly popular and effective vehicle for preparing highly qualified special education teachers in rural areas (Brownell, Bishop, \& Sindelar, 2005; Ludlow \& Brannon, 1999; Spooner, F. Spooner, Algozzine, \& Jordan, 1998). Distance education programs use a wide variety of technology-mediated formats, such as two-way real time video or audio that connects the instructor in one location with students in another location (Cox, Carr, \& Hall, 2004), asynchronous online courses that permit instructors and students to interact at times of their own choosing (DeNeui \& Dodge, 2006; Steinweg, Davis, \&
Thomson, 2005), and to maximize the benefits of both methods, hybrid formats that combine two-way real time video or audio and online coursework (Collins \& Berge, 1998; Shen, Wang, \& Pan, 2008; Teng \& Taveras, 2004). The results of several studies indicate that technology-mediated courses lead to similar endof-semester outcomes when compared to traditional face-to-face courses (Carmel \& Gold, 2007; Schrum, Burbank, \& Capps, 2007; Smith, S. B., Smith, and Boone, 2000; Spooner, F., Jordan, Algozzine, \& Spooner, 1999; Steinweg et al., 2005).

On the downside, distance education programs may require students to work in relative isolation with much weaker connections to teachers and peers (DiRamio \& Wolverton, 2006; Everhart, 1999; Misanchuk \& Anderson, 2001; Motteram \& Forrester, 2005). Although many distance education instructors use strategies, such as online discussion forums and chat rooms, to establish and maintain online or electronic learning communities (Bradford, Porciello, Balkon, \& Bachus, 2007; Motteram \& Forrester, 2005), some students are timid about this type of "public" posting (Conrad, 2002; McSporran \& Young, 2002). This feeling of isolation that results from the lack of personalized attention from faculty and fellow students, along with increased family and personal demands that compete with students' commitment to course completion, has been associated with higher attrition rates in distance education programs than in traditional campus-based programs (Carr, 2000; Morris \& Finnegan, 2009). Attrition rates average about $10 \%$ higher in online courses than face-to-face classes and

\footnotetext{
${ }^{1}$ Address all correspondence to Nancy Glomb (nancy.glomb@usu.edu), Department of Special Education and Rehabilitation, Utah State
} University, Logan, UT. 
course completion rates are typically about 10-20 percentage points lower (DiRamio \& Wolverton, 2006). It has been suggested that too much attention has been paid to recruitment and not enough to retention (DiRamio \& Wolverton, 2006), and distance programs are increasingly challenged to implement strategies that will support students to graduation.

For higher education students living in rural settings, this sense of isolation may be intensified (Menlove \& Lignugaris/Kraft, 2004; Smith-Canter, Voytecki, \& Rodriguez, 2007). In addition to the difficulties faced by other distance education students, rural students face obstacles, such as accessing highspeed internet and proximity to broadcast sites. The unique challenges of rural education require specialized supports to ensure these students receive the same opportunities as students from urban or suburban areas.

\section{The Special Education Distance Program at Utah State University}

The Mild/Moderate Distance Degree and Licensure Program at Utah State University (USU) began in 1995 to address critical shortages in the rural and remote areas of the state. The program is affiliated with 11 USU Regional Campuses and Centers located throughout the state. As a public land-grant university, these regional campuses and centers support and facilitate the delivery of quality courses and degree programs to students who are unable to access traditional campus-based programs. Most delivery sites for the USU distance program are located in rural areas ranging from 40 to 400 miles from the USU campus, and each delivery site accommodates between 2 and 6 students. Distance courses are taught by USU's Department of Special Education and Rehabilitation faculty and delivered via web-augmented classes that include approximately 50\% "live" synchronous instruction via a two-way audiovisual internet system and $50 \%$ asynchronous online instruction. The distance program is offered on a six-semester cycle and delivers the same 51-credit program as the on-campus program. Distance program students participate in clinical experiences in their own local schools and are supervised by local teachers and by USU faculty via webcams. Twenty-two school districts across the state partner with the USU distance program to provide clinical experiences for distance program participants. Students who participate in the USU distance education program fulfill the same requirements as students who participate in the traditional campusbased program at the Logan campus, and successful completion of this program leads to a Bachelor's of Science degree in special education and a Utah K-12 teacher license.

Although students in the distance program attend synchronous classes every other week at the regional campuses, interacting with classmates outside of class time is challenging. Students often drive 30 to 60 miles to attend classes, and job and family responsibilities take up much of their time. In addition, most of these students have several years of distance education experience via online coursework that has created a culture of isolation. In the spring of 2004, the program director conducted a survey of students who left the distance program prior to graduation, and feelings of isolation and a perceived lack of academic and emotional support were cited as the primary reason. These results, and the fact that the attrition rate for program cohorts prior to 2004 averaged $47 \%$, led to the examination of strategies which might promote retention and support program participants.

\section{An Antidote for Isolation and Program. Attrition: Regional Mentors and Learning Communities}

Learning communities tend to form naturally in campus-based courses. Students walk to and from classes together, arrange times to study together, and meet in the university student center for breaks. Research has identified two main functions of learning communities: (a) affective support and (b) course-based connections (Andrade, 2008; Buch \& Spaulding, 2008; Rovai, 2002). Reinforcing and facilitating learning communities is a strategy that has been used to decrease attrition rates in traditional campus-based programs (Cross, 1998; Shapiro, 1998). It has been hypothesized that, because there is a high rate of attrition connected with distance education programs and because the establishment of learning communities has been connected with lower attrition rates in traditional educational settings, there is a good likelihood that applying principles of learning communities to distance education could have similar positive outcomes (DiRamio \& Wolverton, 2006).

To address some of the issues associated with attrition in the Mild/Moderate Distance Degree and Licensure Program at USU, a strategy for establishing regional learning communities was implemented in 2004 to support program participants. Graduates of the program within each broadcast region are employed through a Utah State Office of Education grant to serve as site mentors to distance program students. To be considered for this position, they must have graduated in good standing from the distance program and be employed as a special education teacher in a public school district. Because site mentors serve as liaisons between the school districts in their locality and the program director, feedback from school district supervisors is also considered. Site mentors typically spend 2-3 hrs per week working with the students in their locality, and they are paid $\$ 20$ per hr. They also are 
compensated for travel that constitutes more than 30 miles from their home.

A mentor's primary responsibility is to provide opportunities for emotional and academic support outside of class time. In essence, they engineer local learning communities that take into account the geographic, job, and family constraints of the distance learners within their locality.

Site mentor training. To help the statewide group of site mentors in developing and maintaining their respective learning communities, a 2-day workshop is offered at USU's main campus each summer. The training is facilitated by the program director and the program academic advisor. The first day focuses on academic support. It begins with an overview of the scope and sequence of the distance program for the upcoming academic year. New faculty and instructors are introduced; broadcast and online schedules are discussed. To maximize their ability to provide academic support, site mentors serve as teaching assistants for program courses. Faculty use this opportunity to discuss and model major assignments and discuss protocols for communicating with faculty and staff. Site mentors also arrange placements for classroom-based experiences. Faculty expectations for upcoming practica are reviewed, and a timeline for establishing placements is provided.

The program advisor provides each mentor with planning guides for the istudents he or she serves. The program advisor also schedules mid-semester progress meeting for the coming year. These meetings, conducted throughout the state at the regional campuses, provide the program advisor with 2 to 3 faceto-face meetings each year with every distance student, and site mentors participate in these meetings. The first day of the workshop ends with a brainstorming session that focuses on identifying key points in the coming year when students typically need assistance with major assignments and scheduling times during each semester when study sessions will be offered.

The second day focuses on strategies and guidelines for providing emotional support and on strategies for facilitating study sessions and social opportunities. During the morning session, the project director provides instruction in active listening and provides opportunities for role play and practice. The importance of establishing boundaries and defining where support stops and "enabling" begins is also discussed. Experienced mentors are encouraged to share experiences and describe strategies for navigating through difficult situations. During the afternoon, strategies for facilitating study sessions and social activities are discussed. This can be particularly challenging during a sțudent's first semester in the distance program because many distance learners expect to be isolated and they resist invitations to group activities. This session begins with an activity that requires each site mentor to list the unique characteristics of the learners in his or her group, such as family demands, job schedules and geographic distance from the broadcast site or other potential gathering spots. After each mentor has developed a profile of the unique needs of his or her group, mentors reconvene as a group and generate a list of strategies for facilitating group activities. Examples of strategies that have been used successfully are Saturday morning study sessions that include child care, pizza parties before broadcast classes that focus on reviewing material for a test, "Grub and Gripe" weekend lunch or dinner activities, My Space chat sessions, and web-based conferencing meetings. The session ends with each site mentor submitting a tentative schedule and description of at least two group activities for the fall semester - one that focuses on academic support and one that focuses on emotional support. Site mentors receive ongoing support and direction throughout the year from the project director and the program academic advisor via email correspondence and at the mid-semester progress meetings. A website, developed in 2008 with support from a U.S. Office of Special Education Programs grant, allows site mentors to collaborate via discussion boards and blogs. The website also provides a forum for distance students state-wide to discuss a wide variety of issues related to their participation in the program.

\section{Evidence of the Impact of Regional Learning Communities}

The graduation rates prior to implementation of the site mentor network and related activities ranged from $36 \%$ to $53 \%$. Subsequent to implementing regional learning communities, graduation rates rose to $75 \%$. Responses to the learning community-related question in an online program evaluation that is completed by program graduates suggests that these activities contributed to program participants' successful graduation. Graduates are asked about the extent to which their classes and field-based experiences were helpful in preparing them to be practicing special education teachers. They also respond to questions about advising and support and they indicate the extent to which those services contributed to their success in the program. With respect to the site mentors and learning community activities, graduates are asked to rate the extent to which their site mentor and the outside-of-class activities with their local learning community were helpful during their participation in the program. A four-point scale is provided $(4=$ extremely helpful, 3 = adequate, 2 = somewhat helpful, and $1=$ not helpful at all). Of the 30 students who graduated in 2005 (the first group of participants to receive mentoring support), 28 responded to the online survey. Their mean rating to the site mentor/learning 
community question was 3.7. Of the 29 students who graduated in 2007,28 responded. Their mean rating to the site mentor/learning community question was 3.8 . Typical comments associated with this question were, "It was very comforting to know that I did not have to do it alone," "I could not have survived the past 2 years without my group." "Getting together outside of class was sometimes difficult to do but worth it - I felt like I was really in college!" and "I feel as though these people will be my friends for the rest of my life."

\section{Conclusion}

Reinforcing and facilitating learning communities is a strategy that has been used to decrease attrition rates in traditional campus-based programs, and it has been hypothesized that applying the same principles of learning communities could have similar positive outcomes in distance education programs. To facilitate the development and maintenance of regional learning communities within the Mild/Moderate Distance Degree and Licensure Program at USU, highly successful graduates of the program were hired within each broadcast locality to engineer regional opportunities for group studying and socialization. Program graduates who evaluated learning community activities indicated that those experiences were very helpful as they progressed through the courses and practica. Moreover, graduation rates increased from

\section{References}

Andrade, M. S. (2008). Learning communities: Examining positive outcomes. Journal of College Student Retention: Research, Theory, and Practice, $9(1), 1-20$.

Bradford, P., Porciello, M., Balkon, N., \& Bachus, D. (2007). The Blackboard learning system: The be all and end all in educational instruction? Journal of Educational Technology Systems, 35(3), 301-314.

Braun, T. (2008). Making a choice: The perceptions and attitudes of online graduate students. Journal of Technology and Teacher Education, 16(1), 63-93.

Brownell, M. T., Bishop, A. M., \& Sindelar, P. T. (2005). NCLB and the demand for highly qualified teachers: Challenges and solutions for rural schools. Rural Special Education Quarterly, 24(1), 9-15.

Buch, K., \& Spaulding, S. (2008). A longitudinal assessment of an initial cohort in a psychology learning community. Teaching of Psychology, 35(3), 189-193.

Carmel, A., \& Gold, S. S. (2007). The effects of course delivery modality on student satisfaction and retention and GPA in on-site ps. bybrid courses. (ERIC Document Reproduction Services No. ED496527).

Carr, S. (2000). As distance education comes of age, the challenge is keeping the students. Chronicle of Higher Education, 46(23), A39.

Collins, M. P., \& Berge, Z. L. (1998). Using web-conferencing with primary interactive television courses. Proceeding of the $14^{\text {th }}$ Annual Conference on Distance Teaching and Learning, Madison, WI. (ERIC Document Reproduction Services No. 422849).

Conrad, D. (2002). Deep in the hearts of learners: Insights into the nature of online community. Journal of Distance Education, 17(1), 1-19.

Cox, G., Carr, T., \& Hall, M. (2004). Evaluating the use of synchronous communication in two blended courses. Journal of Computer Assisted Learning, 2O(3), 183-193.
$53 \%$ to $75 \%$ since the inception of this approach.

As the distance education program increases its geographic footprint in the state, and as the areas served become increasingly rural and remote, engaging virtual strategies for studying and socializing will need to be added. The multi-user virtual environment Second Life has recently been added to provide program participants in remote areas of the state with opportunities to visit with classmates outside of class time or engage in course-based group activities without having to travel long distances. Participants in Second Life, a virtual internet-based world, create avatars that become virtual manifestations of themselves. Within Second Life, avatars can engage in a full range of activities including interacting with other avatars. Originally developed for recreational use, more than 150 colleges and universities world wide use Second Life to offer virtual educational experiences (Foster, 2007). Two research studies are planned that will evaluate the efficacy of this venue.

It is clear is that reducing the feelings of isolation is important for the success of rural learners in distance education programs. The development of learning communities and social networks can mitigate this problem. Moreover, geographically distributed mentors can help to accomplish this and in so doing improve student success, student satisfaction, and graduation rates.

Cross, K. P. (1998). Why learning communities? Why now? About Campus, 3(3), 4-11.

DeNeui, D. L., \& Dodge, T. L. (2006). Asynchronous learning networks and student outcomes: The utility of online learning components in hybrid courses. Journal of Instructional Psychology, 33(4), 256-259.

DiRamio, D. \& Wolverton, M. (2006). Integrating lcarning communities and distance education: Possibility or pipedream? Innovative Higher Education, 31(2), 99-113.

Everhart, R. L. (1999). Creating Virtual Communities. Syllabus, 12(8), 12-16.

Foster, A. (2007). Professor avatar: In the digital universe of second life, classroom instruction also takes on a new personality. Chronicle of Higher Education, 54(4), 24.

Katsiyannis, A., Zhang, D., \& Conroy, M. A. (2003). Availability of special education teachers: Trends and tests. Remedial and Special Education, 24(4), 246-53.

Ludlow, B.L. \& Brannon, S.A. (1999). Distance education programs preparing personnel for rural areas: Current practices, emerging trends, and future practices. Rural Special Education Quarterly, 18(3), 5-20.

Menlove, R., \& Lignugaris/Kraft, B. (2004). Preparing rural distance education preservice teachers to succeed. Rural Special Education Quarterly, 23(2), 18-26.

McSporran, M. \& Young, S. (2002). Community Building: Facilitating Successful Online Courses. E-learn -2002, Oct 15-19. (ERIC Document Reproduction Services No. 478591).

Misanchuk, M. \& Anderson, T. (2001). Building community in an online learning environment: Communication, cooperation and collaboration. Proceedings of the Annual Mid-South Instructional Technology Conference, Murfreesboro, TN. (ERIC Document Reproduction Services No. ED463-725). 
Morris, L. V., \& Finnegan, 'C. L. (2008). Best practices in predicting and encouraging student persistence and achievement online. Journal of College Student Retention: Research, Theory, and Practice, 1O(1), 55-64.

Motteram, G. \& Forrester, G. (2005). Becoming and online distance learner: What can be learned from students' experiences of induction to distance programmes? Distance Education, 26(3), 281-298.

Parsad, B. \& Lewis, L. (2008). Distance education at postsecondary institutions: 2006-7. First Look. National Center for Education Statistics. 2009-044. (ERIC Document Reproduction Services No. ED503770).

Riffell, S. K., \& Sibley, D. F. (2004). Can hybrid course formats increase attendance in undergraduate environmental science courses? Journal of Natural Resources and Life Science Education, 33, 16-20.

Rovai, A. P. (2002). Sense of community, perceived cognitive learning, and persistence in asynchronous learning networks. Internet and Higher Education, 5(4), 319-332.

Schrum, L., Burbank, M. D., \& Capps, R. (2007). Preparing future teachers for diverse schools in an online learning community: Perceptions and practice. Internet and Higher Education, 10(3), 204-211.

Shapiro, N. (1998). Learning communities: Moving beyond classroom walls. Metropolitan Universities: An International Forum, $9(1), 25$ 34.

Shen, R., Wang, M., \& Pan, X. (2008). Increasing interactivity in blended classrooms through a cutting-edge mobile learning system. British Journal of Ed ucational Technology, 39(6), 1073-1086.

Smith Canter, L. L., Voytecki, K. S., \& Rodriguez, D. (2007). Increasing online interaction in rural special education teacher preparation programs. Rural Special Education Quarterly, 26, 23-27.
Smith, S. B., Smith, S. J., \& Boone, R. (2000). Increasing access to teacher preparation: The effectiveness of traditional instructional methods in an online learning environment. Journal of Special Education Technology, I5(2), 37-46.

Spooner, F., Jordan, L, Algozzine, B., \& Spooner, M. (1999). Student ratings of instruction in distance learning and on-campus classes. Journal of Educational Research, 92(3), 132-140.

Spooner, F., Spooner, M., Algozzine, B., \& Jordan, L. (1998). Distance education and special education: Promises, practices, and potential pitfalls. Teacher Education and Special Education, 14, 121-131.

Steinweg, S. B., Davis, M. L., \& Thomson, W. S. (2005). A comparison of traditional and online instruction in an introduction to special education course. Teacher Education and Special Education, 28(1), 6273.

Sundeen, T. H., \& Wienke, W. D. (2009). A model for recruiting and preparing new rural special educators: Mining an untapped potential. Rural Special Education Quarterly, 28, 3-10.

Teng, T., \& Taveras, M. (2004). Combining live video and audio broadcasting, synchronous chat, and asynchronous open forum discussions in distance education. Journal of Educational Technology Systems, $33(2), 121-129$.

Williams, J. M., Martin, S. M., \& Hess, R. K. (2002). Personnel preparation and service delivery issues in rural areas: The state of the art. Rural and Special Education Quarterly, 21(4), 3-11.

Yudko, E., Hirokawa, R., \& Chi, R. (2008). Attitudes, beliefs, and attendance in a hybrid class. Computers \& Education, 50(4), 1217-1227. 
Copyright of Rural Special Education Quarterly is the property of ACRES and its content may not be copied or emailed to multiple sites or posted to a listserv without the copyright holder's express written permission.

However, users may print, download, or email articles for individual use. 